\title{
12. THE VISUAL ART FROM IASI BETWEEN TRADITION AND INNOVATION
}

Mirela Ştefănescu ${ }^{94}$

\begin{abstract}
After December 1989 in visual art from Iasi were produced numerous changes which have contributed to a new approach of the artistic phenomenon. That was the moment when a new generation of artists appeared and who, unshackle by the rigors of the communist regime, they have created artworks by experimenting the most varied ways of visual expression. An important aspect of this transition period is the place which visual art has it in the culture from Iasi and the aesthetic trends learned by the new generation alongside older artistic directions define the value of the contemporary cultural heritage from Iasi. Also, an important role in the presentation of the visual art from Iasi is the artistic education, which it's in a constant development with the advent of new specializations within the Faculty of Visual Arts and Design, highlighting the artistic and scientific potential of the professors and the students of ,, George Enescu” Național University of Arts from Iasi.
\end{abstract}

Key words: artistic phenomenon, the new generation, visual expression, transition

\section{Introduction}

The contemporary world is monopolized and dominated by techniques which generate changes on the pace of evolution and development of the contemporary culture and civilization. These changes generated by the level and the requirements of social life recommend changes especially in terms of adaptability of human being. The perceptual experiences context in which modern man is engaged requires, first, a change in mental attitude capable of facilitating, other than the traditional concepts, understanding the new phenomena occurring or about to occur. „The 20th century remain in the history of art through constant redefinition of the field of Visual Arts. Creative energies were channeled more on searching of new mediums of expression than on deepening and plastic styles claimed by various artistic groups" (Ștefănescu, 2014, p. 259).

The artists of the twentieth century had to try, actually, the originality, than the artistic talent which we admire at the great artists of the past, being always looking for new challenges, something that never has been seen before. The collapse of the totalitarian system in December 1989 marked the beginning of the search for new artistic directions, alternative, a new approach of artistic phenomenon by experimentation of new technologies, the reorganization of the institutions or setting up of $n e w^{95}$ ones in the new reality of the globalization.

\footnotetext{
94 Doctoral Candidate / "George Enescu" National University of Arts from Iaşi, Romania, email: mirela_stefanescu@yahoo.com

95 A relaxation of the cultural and artistic life made its presence felt since the 60s, though I only remember rebirth Faculty of Design in Iasi, of the PI 3 years, followed by reinstatement of the Faculty of Fine Arts built in 1977 Conservatoire George Enescu but mostly through contacts and exchanges with the West and pioneering cultural achievements. View Ioana Olaru Iulia, Anniversary Time: 155 Years of Art - Related Education in Iasi. The Crisis Years 1989 up to the moment Artistic Liberalization in vol. The International Scientific Conference
} 
Thus, in Romania there are more individual initiatives for opening the West to Eastern Europe. First, the spread of Soros Centers for Contemporary Art in the eastern part of Europe which had a role in supporting Romanian culture promote young artists, the implementation of a new artistic genres and techniques facilitating "the familiarizing of the artists with clear experimental and ideological options, with new media, as well as their access to the high technology to current information, the presence to the major international events and training centers for the artists which have the multidisciplinary grounding, ethnic training in this global world" (Titu, 2003, p. 56).

In the socio-political context after December 1989 it emerged a new generation of artists which acting under the impulse of the outpouring compensating (Cârneci, 2000 p. 195), giving up to artistic production way, marked by the totalitarian ideology, desiring the integration into a system of Western civilization and culture. „The integration of the east - European artist in the modernity adventure through the mechanism of "the cultural of the state" and by the production of centralized and controlled art represents an "absolute novelty" or if it's an alternative short-circuited of the mechanism in which all European artists become integrated into the industrial society. Unless the both routes - the Western and Eastern Europe - are, actually, two complementary mechanisms of a single phenomenon of modern culture" (Idem, p. 196).

\section{The recovery of artistic gap from Romania regarding the West}

The transition from communist regime to the new democracy is seen as a new stage in which artists were unfettered by the requirements imposed by the communist regime, creating uncensored artworks by experimenting the most varied ways of visual expression. Romanian artists focuses on recovery of the art from golden period, controlled by the communist system trying to keep up with the aesthetic trends of the era (the Western art). We can see the eastern European case as a distinct form of modern European universe, which must be integrated into European history and culture, the harmonization is seen like an experience of modernity with all its specificities. Through the artistic events which appeared after decembre 1989 especially those performance type, the visual artists wanted to overcome the gap "to bring out the light the phenomena which are not available to the public " (Titu, 2003, p. 59), feeling the need to recover artistic expressions which was in top in the 50s - 60s.

The performance Festivals such as: AnnART - initiated by Baasz Imre 1990 to the St. Ana Lake from the St. George area, The Zona which was initiated in 1993 by Ileana Pintilie at Timisoara and the Periferic opened by Matei Bejenaru in 1997 in Iasi they appeared in the early years of democracy, in a time when the artists were in search of a cultural identity, of an alternative artistic expression, uncensored. „Performance art has gradually conquered followers and audience in Romania in the 1990s. There are some artists which

Discourse as a Form of Multiculturalism in Literature ans Communication (Petru Maior University, Targu Mures, 3 to 4 December., 2015), Ed. XXI Archipelago Press, 2015 ISBN: 978-606-8624-21-1, pp. 103 
frequent use it as a means of artistic expression" (Guță, 1999). Compared with AnnArt, which had been unfloding in the Sf. Ana Lake area, and having a structure of activities a little bit different, The Zona and Peripheric had as its starting point the issue of marginality and successful attempt to promote cities Timisoara and Iasi in European national and artistic space.

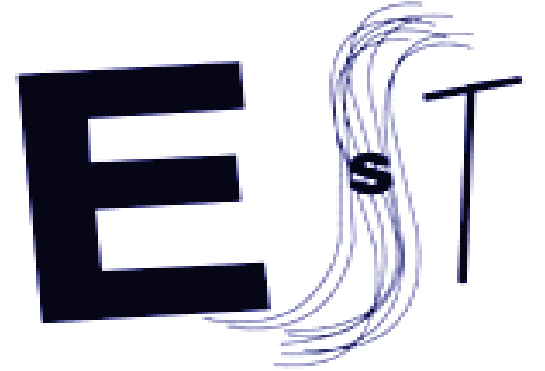

Zona - Europa de Est, Festival de Performance, Ediţia I, Timişoara, 1993

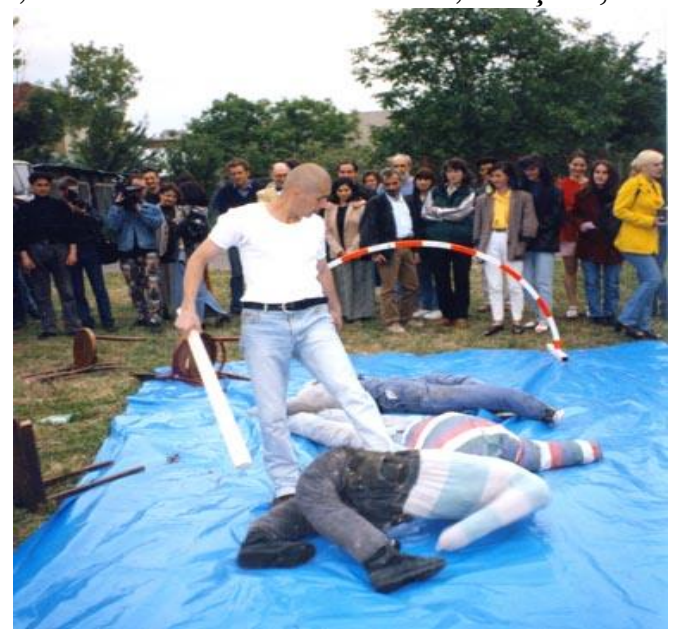

Vlad Horodincă, "Impact", ediția I a Festivalului Periferic ${ }^{96}$

This is a period in which the artists can express themselves freely uncensored in the public space, having the opportunity to interact with viewers and the generous support and new information and communication technological possibilities these artistic manifestations have become more cohesive and more extensive, actually this was demonstrated by their survival for several years, in hard times and always changing both economically, politically and culturally, too. After 2000 , in the context of a changing society in which technological development is unstoppable, the artists make substantial efforts to know and to implement new technologies in their artwork. The artists explore this complex territory with great interest and they create, by fusion of technical tools with the artistic expression modes, a new kind of art technological arts or multimedia art, being actually, a qualitative leap in the evolution of visual arts.

\section{The artistic education from Iasi in transition period}

An important aspect in this period of transition is artistic education. „Education in the arts is essential to students' intellectual, social, physical, and emotional growth and well-being. Experiences in the arts -in dance, drama, music, and visual arts - play a valuable role in helping students to achieve their

\footnotetext{
${ }^{96}$ http://www.periferic.org/index.php?option=com_content\&view=article\&id=54\&Itemid=147\&lang=ro
} 
potential as learners and to participate fully in their community and in society as a whole" (Rusu \& Chandrinou, 2015). Thus, since 1990 the "George Enescu" Academy of Arts and UAPR and its subsidiary from Iasi have developed continuously ${ }^{97}$ and together, the academy's students being present with exhibitions in all UAP's galleries ${ }^{98}$ or in other cultural centers and institutions ${ }^{99}$ from Iasi. These young artists seeks the most varied ways of visual expression, offering through their spectacular exhibition a broad vision on the artistic scene from Iasi, which is dominated by intense searches.

The impact for the development supported of "George Enescu" National University of Arts ${ }^{100}$ was the dynamisation of the creative energies in local contemporary arts field, with regional and national resonance. The recovery and leveling effort of the artistic approach gap was conducted over a period of several years, during which in addition to painting, sculpture and graphic art several new specializations have been accredited such as: Mural Art and later Conservation and Restoration, Design, History and Theory of Arts (Ștefănescu, 2016). Later, new technologies, new media, video art, computerized art were implemented the process which has culminated with the appearance in the faculties of visual art of new specialisations such as: photo - video and multimedia, the opening a media lab in the National Museum of Contemporary Art from Bucharest, the creation of video studios in Arad and Timisoara (Titu, 2003, p. 60) and also the founding the Contemporary Photography Centre from Iasi.

The "George Enescu" National University of Arts from Iasi, by ,the union of three domains of art-music, visual art and art on stage - can result in the startling releasing of creative energy" (Cozmei, 2010, p. 288) with the objective of ,formation of the future people of art and at the same time, the vigorous affirmation of students and professors in the artistic life of today, in a richer, more contradictory and provocative way" (Ibidem). The continuous reform and evaluations which attended George Enescu University of Arts from Iasi, receiving from ARACIS the high degree of confidence in 2010 and reconfirmed in 2015 is the culmination of prodigious teaching and artistic activities, highlighting the artistic and scientific potential of the professors and the students of our university. „By means of periodical assessment procedures, reports and regulations are made, which permanently determine the change of curricula and syllabi according to the standards of the Romanian Agency for Quality Assurance in Higher Education - ARACIS / ARTS (1), as well as the opportunity of initiating, in the future, new programs, in line with the labor market dynamics" (Pașca, 2016). Thus, the development of the Arts University begins to materialize in the context of prolonged transition and the trend of

\footnotetext{
${ }^{97}$ Noted the increasing number of students and teachers, increasing UAP members -Iaşi, workshops, galleries, artistic events they organize or involvement with other institutions in organizing arts events.

${ }^{98}$ Victoria, Trianon, Cupola

${ }^{99}$ French Cultural Center, Army House, "Marble Hall" of the Faculty of Veterinary Medicine, Gothic Hall of the Three Hierarchs

${ }^{100}$ Starting with the academic year 2016-2017 has been approved by the Ministry of National Education and Scientific Research new name of University of Arts Iasi.
} 
consolidation and internationalization of research and artistic activities are an important and beneficial validation to the level of training and values cultivated in the educational and creative process ${ }^{101}$.

\section{Conclusions}

In a globalized world the visual artists should be flexible and to adapt to new aesthetic trends which gives us other artistic disciplines, which, actually it contribute to the evolution of visual art from the twenty-first century. Thus, a phenomenon worthy to note is the interference of the arts practiced by young artists as a complex show designed by combining several arts in which the means of traditional expression, particular for different fields of art, are inseparable, resulting artworks which are not within in the known artistic genres. „Through the interdisciplinary it realizes a new direction of artistic creation, the relations, established between different areas, gives an enriched overview about reality, integrating them can fulfill their role much more effectively than would be considered separately" (Ștefănescu, 2016, p. 146).

Now is the time that the accumulation of knowledge is unprecedented in human history, and the interdisciplinarity allows us to have an open vision of dialogue between all disciplines both in science and humanities fields, such as: arts, literature, poetry, and the transdisciplinarity includes "what they have in common and what it's beyond their borders" (Nicolescu, 2007, p. 174). Thus, the influence of globalization and current technological changes have prompted the artists to seek those general criteria which to match the best treated subjects, adding new dimensions to the creative process through artistic means adequate for a dynamic world and evolving, resulting astounding and various creations. "Contemporary artist's tendency is to release the designs and figurative traditions of the past, in order to consecrate the contemporary world, dynamic and constantly evolving" (Ștefănescu \& Ștefănescu, 2014, p. 241).

An important aspect of this transition period is the place which visual art has it in the culture from Iasi and the aesthetic trends learned by the new generation alongside older artistic directions define the value of the contemporary cultural heritage from Iasi. The particularity of visual art from Iasi is relvant by the cultural and artistic ${ }^{102}$ events which have a special importance at the national and European level and which are well reflected by critics and the media.

\section{Bibliography}

1. Bartos, J. (2006). Arta murală, interferențe vizual-artistice. Iași: Artes.

2. Bartos, J. (2009). Compoziţia în pictură. Iași: Polirom.

3. Bauman, Z. (2008). Globalizarea şi efectele ei sociale. Prahova: Antet.

4. Cârneci, M. (2000). Artele plastice în România 1945-1989. București: Meridiane.

\footnotetext{
${ }^{101}$ Viorel Muntenu quoted Rector of the opening of the academic year 2010

${ }^{102}$ We refer, in particular, to the visual arts, represented by professional institutions.
} 
5. Colţa, O. (2008). Exerciţii de reflecţie. Timișoara: Editura Fundaţiei Interart Triade/Brumar.

6. Cozmei, M. (2010). Pagini din istoria invațamăntului artistic modern din Iași la 150 de ani (2nd ed.). Iași: Artes.

7. Flichy, P. (1999). O istorie a comunicării moderne. Iași: Polirom.

8. Gablik, S. (2008). A eşuat modernismul? București: Curtea Veche.

9. Geert, L. (2004). Cultura digitală. Cluj: Idea Design/Print.

10. Guţă, A. (2008). Generaţia '80 în artele vizuale. Pitești: Paralela 45.

11. Guță, A. (1999). AnnART 10. România Literară, 44.

12. Korten, D. C. (2001). Globalizarea societăţii civile. Conn: Boomfield.

13. Maliţa, M. (1998). Zece mii de culturi, o singură civilizaţie. București: Nemira.

14. Meredieu, F. (2004). Arta şi noile tehnologii. București: Enciclopedia RAO.

15. Nicolescu, B. (2007). Transdisciplinaritatea - Manifest. Iași: Junimea.

16. Pașca, E. M. (2016). Variables and constants in the curriculum for the music specialisations of the romanian university education. Review of Artistic Education, 11/12, 33-45.

17. Pintilie, I. (1999). Acţionismul în România în timpul comunismului. Cluj: Idea.

18. Pintilie, I. (2006). Timișoara între tradiție și modernitate. Timișoara: Editura Fundației Interart Triade Brumar.

19. Popa, D. (2002). Mass-media, astăzi. Iași: Institutul European.

20. Raţiu, D. (2001). Disputa modernism-postmodernism. Cluj: Dacia.

21. Rusu, M. \& Chandrinou, T. (2015). Characteristics and principles of art education. Review of Artistic Education, 10/11, 44-54.

22. Sava, V. (2010). Învăţământul artistic naţional ieşean şi vocaţia lui europeană. Iași: Artes.

23. Ştefănescu, M. \& Ştefănescu M. (2014). Land Art - The harmony between art, nature, landscape. Revista Lucrări Științifice a Facultății de Horticultură din cadrul USAMV Iași, 57(2), 55-67.

24. Ștefănescu, M. (2014). Seria Puppyes creată de Jeff Koons. Revista Lucrări Științifice a Facultății de Horticultură din cadrul USAMV Iași, 57(2), 12-23.

25. Ștefănescu, M. (2016). "George Enescu” University of Arts - the anniversary of 155 years since the establishment of modern artistic education in Iasi. In E.M. Pașca (Ed.) Dimensiuni ale Educației Artistice (vol. 12). Iași: Artes.

26. Ştefănescu, S. \& Velicu, A. (2006). Naţional şi/sau european? Reprezentări sociale ale identităţii în societatea românească actuală . București: Expert.

27. Titu, A. (2003). Experimentul în arta românească după 1960. București: Meridiane.

28. Tomlinson, J. (2002). Globalizare şi cultură. Timișoara: Amarcord.

29. Vlad, T. (2008). Antropologia Artei contemporane. Iași: Artes.

30. Zaharia, D.N. (1995). Iaşul Vernisajelor (1st vol.). Iași: Cariatide.

31. Zaharia, D.N. (1999). Antinomicul în arta contemporană. Iași: Dosoftei.

32. Zaharia, D.N. (2000). Iaşul Vernisajelor (2nd vol.). Iași: Dosoftei. 